\title{
Thyroid hormone levels associate with exposure to polychlorinated biphenyls and polybrominated biphenyls in adults exposed as children
}

Sarah W. Curtis ${ }^{1}$, Metrecia L. Terrell ${ }^{2}$, Melanie H. Jacobson², Dawayland O. Cobb', Victoria S. Jiang ${ }^{1}$, Michael F. Neblett', Sabrina A. Gerkowicz' ${ }^{1}$ Jessica B. Spencer', M. Elizabeth Marder², Dana Boyd Barr², Karen N. Conneely ${ }^{3}$, Alicia K. Smith ${ }^{1 *}$ (D) and Michele Marcus ${ }^{2}$

\begin{abstract}
Background: Michigan residents were directly exposed to endocrine-disrupting compounds, polybrominated biphenyl (PBB) and polychlorinated biphenyl (PCB). A growing body of evidence suggests that exposure to certain endocrine-disrupting compounds may affect thyroid function, especially in people exposed as children, but there are conflicting observations. In this study, we extend previous work by examining age of exposure's effect on the relationship between PBB exposure and thyroid function in a large group of individuals exposed to PBB.

Methods: Linear regression models were used to test the association between serum measures of thyroid function (total thyroxine $\left(T_{4}\right)$, total triiodothyronine $\left(T_{3}\right)$, free $T_{4}$, free $T_{3}$, thyroid stimulating hormone $(T S H)$, and free $T_{3}$ : free $\mathrm{T}_{4}$ ratio) and serum PBB and PCB levels in a cross-sectional analysis of 715 participants in the Michigan PBB Registry.

Results: Higher PBB levels were associated with many thyroid hormones measures, including higher free $T_{3}(p=$ $0.002)$, lower free $T_{4}(p=0.01)$, and higher free $T_{3}$ : free $T_{4}$ ratio $(p=0.0001)$. Higher PCB levels were associated with higher free $T_{4}(p=0.0002)$, and higher free $T_{3}$ : free $T_{4}$ ratio $(p=0.002)$. Importantly, the association between PBB and thyroid hormones was dependent on age at exposure. Among people exposed before age $16(N=446)$, higher PBB exposure was associated with higher total $T_{3}(p=0.01)$ and free $T_{3}(p=0.0003)$, lower free $T_{4}(p=0.04)$, and higher free $T_{3}$ : free $T_{4}$ ratio $(p=0.0001)$. No significant associations were found among participants who were exposed after age 16. No significant associations were found between TSH and PBB or PCB in any of the analyses conducted.
\end{abstract}

Conclusions: This suggests that both PBB and PCB are associated with thyroid function, particularly among those who were exposed as children or prenatally.

Keywords: Endocrine disrupting compound, EDC, PBB, PCB, Age at exposure, Children's health, Triiodothyronine, Thyroxine, Thyroid-stimulating hormone, DOHaD

\footnotetext{
* Correspondence: alicia.smith@emory.edu

'Emory University School of Medicine, 101 Woodruff Circle NE, Ste 2205A,

Atlanta, GA 30322, USA

Full list of author information is available at the end of the article
}

(c) The Author(s). 2019 Open Access This article is distributed under the terms of the Creative Commons Attribution 4.0 International License (http://creativecommons.org/licenses/by/4.0/), which permits unrestricted use, distribution, and reproduction in any medium, provided you give appropriate credit to the original author(s) and the source, provide a link to the Creative Commons license, and indicate if changes were made. The Creative Commons Public Domain Dedication waiver (http://creativecommons.org/publicdomain/zero/1.0/) applies to the data made available in this article, unless otherwise stated. 


\section{Background}

Exposure to endocrine-disrupting compounds (EDCs) is prevalent in the modern world. EDCs are present in most plasticizers, pesticides, personal care products, flame retardants, and electronic waste [1-3]. Increased exposures have been associated with the development of cancer, reproductive problems, and hormone dysfunction [4, 5]. Especially troubling, children are believed to be particularly susceptible to the effects of EDCs, with children exposed to EDCs in utero or early in life being at increased risk of problems with reproduction, pubertal development, neurodevelopment, and obesity [6]. However, many of the studies do not have a clear dose-response relationship between higher EDC exposure and health problems, and different studies have inconsistent results.

In 1973, millions of Michigan residents were exposed to polybrominated biphenyl (PBB), a brominated flame retardant and an EDC, when a factory accident caused it to be added to the food supply [7, 8]. The Michigan Chemical Company (owned by the Velsicol Chemical Company) mistakenly shipped approximately 500-1000 pounds of PBB to the Farm Bureau Services, where it was added to livestock feed [7, 8]. Animals across the state were exposed when they ate the contaminated feed. During the 10-month period preceding this discovery and the subsequent quarantine of affected farms, Michigan residents were exposed by eating contaminated meat and dairy $[7,8]$. In the aftermath, the people who were believed to have the highest direct exposure people living on or obtaining food from quarantined farms and the Michigan Chemical Company's workers and their families - were recruited to investigate the long-term health effects of PBB exposure. These participants, their children, and other members of the community have been followed for the past 40 years as part of the Michigan PBB Registry and have had their current serum levels of $\mathrm{PBB}$ regularly assessed, as well as their exposure to the structurally-related polychlorinated biphenyl (PCB), which they were continuously exposed to from typical environmental sources [7-9].

A majority of participants of the Michigan PBB Registry still have detectable PBB levels 40 years after the incident because $\mathrm{PBB}$ is lipophilic and biologically persistent $[10,11]$. Additionally, PBBs are transferred across the placenta and are present in the breast milk of exposed women, meaning that their children, even those born decades after the incident, can be exposed to PBB during development [12]. People exposed to PBB in utero or as children have been shown to have an increased risk of endocrine-related health conditions, and may experience unique problems compared to those exposed as adults [9]. For example, women exposed to PBB in utero were found to be at increased risk for earlier menarche and spontaneous abortions, while women exposed as adults were not found to be at increased risk [13-15]. Further, women exposed in childhood were at an increased risk for having children with lower Apgar scores [16]. Men exposed in utero reported more genitourinary conditions and slower growth and pubertal development $[17,18]$.

PBB and PCB may also disrupt thyroid hormone signaling and lead to thyroid disease given the structurally-similarities between these EDCs and thyroid hormones [4]. Proper thyroid hormone signaling is important for normal development, homeostasis, and cell proliferation [19]. The primary thyroid hormone in the blood is thyroxine $\left(\mathrm{T}_{4}\right)$, which can either be bound to carrier proteins and inactive, or free, biologically-active molecules. All cells in the body are targets for thyroid hormones, making thyroid function particularly important for metabolism and fetal development $[20,21]$. Free $\mathrm{T}_{4}$ is converted to triiodothyronine $\left(T_{3}\right)$ by deiodinases in target tissues, where it can then bind to thyroid hormone receptors. Receptors bound to $\mathrm{T}_{3}$ will then act as transcription factors and cause conformational changes that recruit transcription coactivators to DNA and initiate gene transcription. Smaller amounts of $\mathrm{T}_{3}$ (both bound and free) are also present in the blood stream, as is thyroid stimulating hormone (TSH), which regulates $T_{3}$ and $T_{4}$ production and iodine uptake in the thyroid. Thyroid disease can cause further issues with metabolism and weight, fertility, and attentiveness, while subclinical thyroid function may lead to issues with fertility, fetal development, and increase the risk for cardiovascular disease [22-27].

In animals, exposure to PBBs lowered levels of total $T_{3}$ and $\mathrm{T}_{4}$ and increased thyroid weight (indicative of thyroid conditions like goiters or thyroiditis), and cell lines exposed to $\mathrm{PBB}$ had decreased thyroid hormone mediated gene transcription and decreased dendrite branching [28, 29]. Similarly, studies have shown that increased exposure to PCB associates with thyroid dysfunction, and PCBs can bind to thyroid hormone receptors in rat cell lines [30, 31]. In the developing brains of fetal rats, maternal exposure to PCBs mimics thyroid hormones by driving gene expression and altering cellular composition [32-34]. Studies in humans exposed to PBBs have been less consistent, with some studies finding no association between increased PBB exposure and increased risk for thyroid disease, and others finding increased risk for thyroid disease both in highly-exposed chemical workers and in women [35-37].

This study investigates whether increased $\mathrm{PBB}$ and PCB exposure associates with thyroid hormone levels in members of the Michigan PBB Registry. This is the largest study of thyroid hormone levels and $\mathrm{PBB}$. Because $\mathrm{PBB}$ exposure (unlike PCB exposure) in this cohort occurred during a single, unique time-point, we can also estimate participants' age when exposed to $\mathrm{PBB}$, and test whether their age at exposure to $\mathrm{PBB}$ and current $\mathrm{PBB}$ level predict thyroid function. Additionally, because 
many of the health effects associated with PBB were in those who were exposed when they were young $[9,14$, $15,17,18]$, we can then test whether the association between $\mathrm{PBB}$ exposure and thyroid function differs in people exposed before age 16 compared to those exposed after age 16.

\section{Methods}

\section{Participant selection}

Participants were selected from the Michigan PBB Registry. Recruitment of these participants has been described in detail elsewhere [37]. Briefly, the Michigan PBB Registry was originally started after the agricultural accident by the Michigan Department of Community Health (MDCH), and recruited individuals believed to have the highest exposure to PBB: people living on quarantined farms, people who ate food from quarantined farms, and chemical workers and their families. Biological samples and health information from the original registry participants, their children, and other member of the community who were exposed to PBBs are still being collected and added to the registry (http://pbbregistry.emory.edu/).

For this study, 744 blood samples were selected that had exposure to PBB and PCB already assessed and had remaining serum for hormone analyses. These samples came from 717 participants and were collected between 2004 and 2015. For those with multiple samples over time, the most recent sample was used for each participant. PBB level, PCB level, lipid level, and thyroid hormone level were all analyzed from the same sample. Of those with serum samples, 596 of these participants had completed a health questionnaire, which was used to determine whether they were currently on thyroid medication. Two participants reported being on thyroid medication at the time of their blood draw and were removed from all analyses $(N=715)$. Ten additional participants reported having a thyroid condition, but did not report taking medication. A sensitivity analysis was conducted with just the 584 participants to ensure that the results held in the participants with known thyroid medication status.

\section{Exposure measurement}

The Michigan PBB Registry has been assessed for both $\mathrm{PBB}$ and $\mathrm{PCB}$. There are 209 possible congeners of $\mathrm{PBB}$ and $\mathrm{PCB}$ that exist based on the number and position of the halogen molecules around the biphenyl rings [38]. The primary congener in the technical mixture that contaminated the food supply in the 1970's was PBB-153 [7, 8, 38]. Exposure to four congeners of PBB (PBB-153, PBB-101, PBB-77, and PBB-180) and four congeners of PCB (PCB-153, PCB-180, PCB-138, PCB-118) was previously assessed in members of this registry using gas chromatography-tandem mass spectrometry [39]. The limit of detection (LOD) was $2 \mathrm{pg} / \mathrm{mL}$ for PBB-153; $4.5 \mathrm{pg} / \mathrm{mL}$ for PBB-77; $3.9 \mathrm{pg} / \mathrm{mL}$ for PBB-101; $5.6 \mathrm{pg} / \mathrm{mL}$ for PBB-180; $0.7 \mathrm{pg} / \mathrm{mL}$ for PCB-180; $1.6 \mathrm{pg} / \mathrm{mL}$ for PCB-153; $1.2 \mathrm{pg} /$ $\mathrm{mL}$ for PCB-138; and $1.4 \mathrm{pg} / \mathrm{mL}$ for PCB-118. The extraction recovery ranged from $83.2-99.2 \%$. The accuracy ranged from 89 to $119 \%$, and the precision ranged from $2.8-8.5 \%$. The value for any congener below the LOD in a sample was imputed as the LOD divided by the square root of 2 [40]. The congeners were summed to give a total $\mathrm{PBB}$ value and total PCB value per person. The congeners of $\mathrm{PBB}$ and $\mathrm{PCB}$ were variably correlated with each other with the $\mathrm{PBB}$ congeners being more correlated to each other than to the $\mathrm{PCB}$ congeners (Additional file 1: Figure S1).

\section{Lipid measurement}

A Triglyceride Quantification Assay Kit (Abnova Corporation) was used to measure the total serum triglyceride content, and a Cholesterol Assay Kit (Caymen Chemical Company) was used to measure total serum cholesterol content. Both were done according to manufacturer's instructions. Total lipid amount was calculated based on these components as described elsewhere [41, 42].

\section{Thyroid hormone measurement}

Thyroid hormone levels (total and free $\mathrm{T}_{4}$, total and free $\mathrm{T}_{3}$, and $\mathrm{TSH}$ ) were analyzed from either serum or plasma with a Beckman Coulter Access II chemiluminescent immunoassay (Beckman Coulter) by the Emory Clinical Translational Research Laboratory. All analyses were conducted per manufacturer's instructions, as previously described [37]. Technical replicates were run throughout the experiment and were highly correlated with each other (mean correlation $=0.99$ ). Hormone levels were measured and detectable for all the samples, except for one sample that did not have sufficient quantity for analyzing the total $\mathrm{T}_{4}$ level. Population-based clinical ranges for this assay were used to determine whether any of the samples had thyroid disease (TSH: $0.34-5.60 \mu \mathrm{IU} / \mathrm{mL}$; free $\mathrm{T}_{4}: 0.61-1.12 \mathrm{ng} / \mathrm{dL}$; free $\mathrm{T}_{3}$ : $2.5-3.9 \mathrm{pg} / \mathrm{mL}$; total $\mathrm{T}_{4}$ in women: $5.0-9.80 \mu \mathrm{g} / \mathrm{dL}$; total $\mathrm{T}_{4}$ in men: $6.1-12.2 \mu \mathrm{g} / \mathrm{dL}$; total $\mathrm{T}_{3}: 0.87-1.78 \mathrm{ng} / \mathrm{mL}$ ).

\section{Statistical analyses}

All exposure and hormone values were transformed using a natural $\log$ so that they would be less skewed. A ratio between free $T_{3}$ and free $T_{4}$ was calculated, and since it was already not skewed, it was not transformed. Associations between thyroid hormone levels (as the dependent variable) and exposure to PBB (as the independent variable) were assessed using linear regression models. All models included covariates for age, sex, total PCB level, and total lipid amount. Lipids were adjusted for as a covariate instead of on a wet weight basis to allow for more flexibility and limit 
bias [43]. Additionally, the cohort was subset into whether they had high exposure to $\mathrm{PBB}$, high exposure to $\mathrm{PCB}$, high exposure to both, or high exposure to neither (based on median split). The same models were tested in these subsets separately. We tested for interaction between age of exposure to $\mathrm{PBB}$ and level of exposure by adding an interaction term (age of exposure $\times$ PBB level) to the model. The cohort was also subset into those who were exposed before finishing puberty (defined as their age in 1973 being less than or equal to 16) and those who were exposed after finishing puberty (defined as their age in 1973 being older than 16). Sixteen was chosen as the cut-point in order to be consistent with early studies done in children exposed to PBB [44], more recent studies in this study population $[10,11,45]$, and the approximate age when puberty is complete in the United States [46]. However, to ensure that the associations seen were not due to arbitrary stratification of the data, the cohort was subset into quartiles of age of exposure and by the median age of exposure. In the analyses in these subsets, age, sex, total PCB level, and lipids were covariates. Interaction between PCB and age of exposure to $\mathrm{PCB}$ was not tested because PCB exposure in this cohort was continuous and not during a defined agricultural accident, making us unable to estimate when people were first exposed to PCB. We also tested for interaction between sex and level of exposure by adding an interaction term (sex $\times$ exposure level) to the model. The models were also subset by sex. In the analyses in these subsets, age, total PCB level, and lipids were covariates. An alpha level of 0.05 was used as the cutoff for statistical significance in all analyses.

\section{Results}

Participants of this study $(N=715)$ were highly exposed to PBB (range: 0.01-236.73 ppb; Table 1), with 92\% having PBB levels higher than the median for a representative sample of the United States [47] and exposed to PCB (range: $0.03-8.12 \mathrm{ppb}$ ), at levels similar to typical exposure for people in the United States [3]. There were more female than male participants, and the average age at time of blood draw was 51 years old (range: 18-88 years). Because participants were largely exposed to PBB during a factory accident during the 1970's, age at exposure is correlated with their current age $(r=0.96$; $p<2.2 \mathrm{e}-16)$. Older participants had higher levels of $\mathrm{PBB}$ and PCB (PBB: $r=0.48, p<2.2 \mathrm{e}-16 ;$ PCB: $r=0.59$, $\mathrm{p}<2.2 \mathrm{e}-16)$, and men had higher $\mathrm{PBB}$ and PCB levels than women (PBB: $p=0.01$, PCB: $p=0.0007$ ). This pattern was consistent when the cohort is stratified by those who were exposed before finishing puberty (age 16) versus those who were exposed after finishing puberty.

As expected, most of the thyroid hormone levels were significantly correlated with each other (Fig. 1). For each thyroid assay, a majority of samples were within the usual, population-based range (Additional file 1: Figure S2). A few participants $(N=5)$ had thyroid hormone levels indicative of hypothyroidism (defined as having either a total or free $\mathrm{T}_{4}$ level lower than the populationbased range and having a TSH level higher than the population-based range), and 7 participants had thyroid hormone levels indicative of hyperthyroidism (defined as having either a total or free $\mathrm{T}_{4}$ level higher than the population-based range and having a TSH level lower than the population-based range). Total $T_{3}$, free $T_{3}$, and free $T_{3}$ : free $T_{4}$ ratio were negatively associated with age $(\mathrm{r}=-0.30, p<2.2 \mathrm{e}-16 ; \mathrm{r}=-0.18, p=5.68 \mathrm{e}-7$; and $\mathrm{r}=-$ $0.20, p=3.41 \mathrm{e}-8$, respectively), and free $\mathrm{T}_{4}$ was positively associated with age $(\mathrm{r}=0.09, p=0.01)$. This is reflected in the different means for those three hormones in the group exposed after finishing puberty (age 16) and the group exposed before finishing puberty (Table 2). Thyroid hormone levels were also associated with sex, with men having lower levels of total $\mathrm{T}_{3}(p=0.001)$ and total $\mathrm{T}_{4}(p=0.02)$, and higher levels of free $\mathrm{T}_{3}(p=0.03)$.

In the total cohort, PBB levels were positively associated with free $\mathrm{T}_{3}$ levels $(\mathrm{t}=3.01, p=0.002)$, free $\mathrm{T}_{3}$ : free $\mathrm{T}_{4}$ ratio $(\mathrm{t}=3.90, p=0.0001)$, and negatively associated with

Table 1 Cohort Demographics

\begin{tabular}{|c|c|c|c|c|}
\hline & $\begin{array}{l}\text { Total Cohort } \\
(N=715)\end{array}$ & $\begin{array}{l}\text { Exposed before puberty } \\
(N=446)\end{array}$ & $\begin{array}{l}\text { Exposed after puberty } \\
(N=269)\end{array}$ & $P$-value \\
\hline Current age $^{a}$ (years) & $51.19 \pm 15.21$ & $41.62 \pm 9.53$ & $67.07 \pm 7.73$ & $<2.2 \mathrm{e}-16$ \\
\hline Age exposed ${ }^{\mathrm{a}}$ (years) & $13.60 \pm 12.21$ & $5.47 \pm 5.19$ & $27.08 \pm 7.78$ & $<2.2 \mathrm{e}-16$ \\
\hline Number male ${ }^{b}$ & 275 (38.4\%) & $120(26.9 \%)$ & $155(57.6 \%)$ & $6.28 \mathrm{e}-16$ \\
\hline Total PBB $(p p b)^{c}$ & $0.34(5.79)$ & $0.22(5.73)$ & $0.72(4.48)$ & $<2.2 \mathrm{e}-16$ \\
\hline Total PBB (ng/g lipid) ${ }^{c}$ & $51.11(6.11)$ & $31.84(5.95)$ & $111.99(4.80)$ & $8.39 e-3$ \\
\hline Total PCB $(p p b)^{c}$ & $0.65(2.76)$ & $0.45(2.64)$ & $1.21(2.13)$ & $<2.2 \mathrm{e}-16$ \\
\hline Total PCB (ng/g lipid) ${ }^{c}$ & $98.88(2.83)$ & $66.81(2.63)$ & $189.43(2.24)$ & $<2.2 \mathrm{e}-16$ \\
\hline
\end{tabular}

${ }^{a}$ Mean and standard deviation

${ }^{\mathrm{b}}$ Frequency and percentage

'Geometric mean and geometric standard error

${ }^{\mathrm{d}}$ Exposed before finishing puberty (Age of exposure $<=16$ )

Exposed after finishing puberty (Age of exposure $>16$ ) 

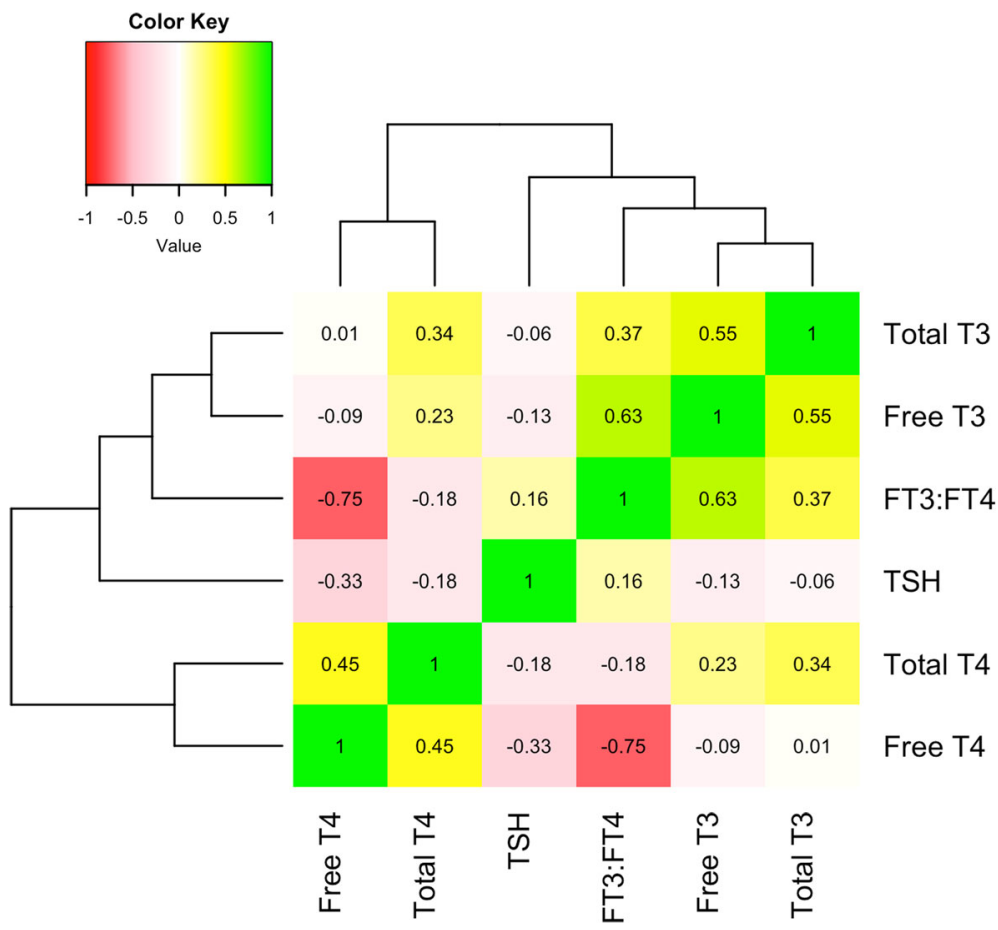

Fig. 1 Correlation of thyroid hormone levels. The different thyroid hormone levels measured in this cohort were correlated with each other, and clustered so that the most correlated hormone levels are together (numbers are Pearson's correlation coefficient). TSH was negatively correlated with the rest of the thyroid hormones, as expected since it is negatively regulated by them, and positively correlated with the free $T_{3}$ : free $T_{4}$ ratio. Total and free $T_{4}$ were moderately correlated, as were total and free $T_{3}$. Total $T_{4}$ was positively correlated with both total and free $T_{3}$. Free $T_{4}$ had a weak correlation with both total and free $T_{3}$. The free $T_{3}$ : free $T_{4}$ ratio is positively associated with total and free $T_{3}$, but was negatively associated with total and free $T_{4}$ (as expected). All correlations were statistically significant except for the association of total $T_{3}$ with free $T_{4}$ and $\mathrm{TSH}(p<0.05)$

free $\mathrm{T}_{4}(\mathrm{t}=-2.64, p=0.008)$. PBB levels were not associated with total $\mathrm{T}_{4}(\mathrm{t}=1.05, p=0.29)$, total $\mathrm{T}_{3}(\mathrm{t}=1.48$, $p=0.13)$, or TSH $(\mathrm{t}=1.30, p=0.19)$ (Fig. 2a, Table 3). $\mathrm{PCB}$, on the other hand, was positively associated with free $\mathrm{T}_{4}(\mathrm{t}=3.63, p=0.0002)$ and negatively associated with the free $\mathrm{T}_{3}$ : free $\mathrm{T}_{4}$ ratio $(\mathrm{t}=-3.03, p=0.002)$. PCB was not associated with total $\mathrm{T}_{4}(\mathrm{t}=0.66, p=0.50)$, total $\mathrm{T}_{3}$ $(\mathrm{t}=1.82, p=0.06)$, free $\mathrm{T}_{3}$ levels $(\mathrm{t}=-0.42, p=0.66)$, or TSH ( $\mathrm{t}=-1.28, \mathrm{p}=0.19)$ (Fig. 2b, Table 3). These associations were consistent when conducted in the subset of participants that reported their thyroid medication status
(Additional file 1: Table S1). Additionally, the direction of the effect of PBB and PCB on thyroid hormone levels was consistent if the population was subset by exposure level to the two chemicals (Additional file 1: Tables S2-S5). There was no statistically significant interaction between gender and PBB to predict any of the thyroid measures (Additional file 1: Table S6), but there was some evidence of an interaction between gender and PCB exposure level to predict free $T_{4}$ and free $T_{3}$ : free $T_{4}$ ratio, with there only being an association between PCB and thyroid hormone levels in women (Additional file 1: Table S7). An

Table 2 Thyroid hormone levels in Michigan PBB Registry

\begin{tabular}{lllll}
\hline & Total Cohort & Exposed before puberty & Exposed after puberty $^{\mathrm{d}}$ & $P$-value \\
\hline${\text { Total } \mathrm{T}_{4}{ }^{\mathrm{a}}(\mu \mathrm{g} / \mathrm{dL})}^{9.06(1.20)}$ & $9.02(1.20)$ & $9.12(1.21)$ & 0.46 \\
Total $_{3}{ }^{\mathrm{a}}(\mathrm{ng} / \mathrm{mL})$ & $1.01(1.26)$ & $1.06(1.25)$ & $0.94(1.24)$ & $1.64 \mathrm{e}-10$ \\
Free $_{4}{ }^{\mathrm{a}}(\mathrm{ng} / \mathrm{dL})$ & $0.78(1.19)$ & $0.77(1.18)$ & $0.80(1.21)$ & $5.09 \mathrm{e}-03$ \\
Free $_{3}{ }^{\mathrm{a}}(\mathrm{pg} / \mathrm{mL})$ & $3.16(1.16)$ & $3.22(1.16)$ & $3.07(1.15)$ & $1.98 \mathrm{e}-05$ \\
TSH $^{\mathrm{a}}(\mu \mathrm{IU} / \mathrm{mL})$ & $1.60(1.97)$ & $1.55(1.93)$ & $1.67(2.03)$ & 0.15 \\
Free $_{3}$ : Free $\mathrm{T}_{4}{ }^{\mathrm{b}}$ & $4.12 \pm 0.90$ & $4.26 \pm 0.91$ & $3.90 \pm 0.85$ & $1.41 \mathrm{e}-07$ \\
\hline
\end{tabular}

${ }^{\mathrm{a}}$ Geometric mean and geometric standard error

${ }^{\mathrm{b}}$ Mean and standard deviation

'Exposed to PBB before finishing puberty (Age of exposure $<=16$ )

dExposed to PBB after finishing puberty (Age of exposure $>16$ ) 

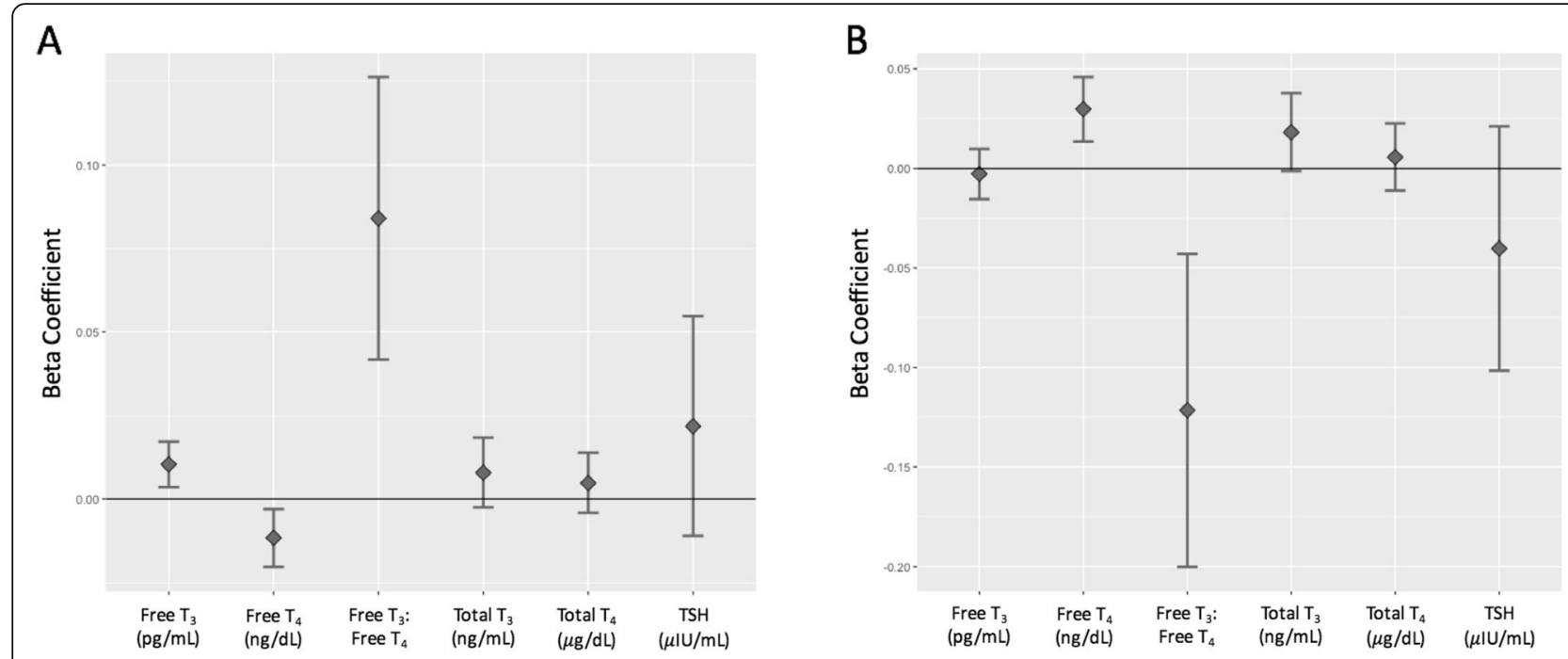

Fig. 2 Association of PBB exposure and thyroid hormone levels. The beta coefficients and 95\% confidence interval (y-axis) for total PBB level (a) and total PCB level (b) from the regression of the five thyroid hormone levels ( $x$-axis), also controlling for age, sex, and lipids. Free $T_{3}(p=0.002)$, free $T_{4}(p=0.008)$, and the free $T_{3}$ : free $T_{4}(p=0.0001)$ ratio are significantly associated with total PBB exposure. Free $T_{4}(p=0.0002)$ and the free $T_{3}$ : free $T_{4}$ ratio $(p=0.002)$ are significantly associated with total $P C B$ exposure

interaction between age of exposure to $\mathrm{PBB}$ and total $\mathrm{PBB}$ level was significant for predicting total $\mathrm{T}_{3}(\mathrm{t}=-2.15, p=$ $0.03)$, free $T_{3}(t=-3.07, p=0.002)$, and the free $T_{3}$ : free $\mathrm{T}_{4}$ ratio $(\mathrm{t}=-2.39, p=0.01$; Fig. 3$)$. The interaction term was not significant for predicting total $\mathrm{T}_{4}(\mathrm{t}=-0.84, p=$
$0.39)$, free $\mathrm{T}_{4}(\mathrm{t}=0.68, p=0.49)$, and TSH $(\mathrm{t}=-0.15, p=$ 0.87 ).

Because there was a significant interaction between exposure and age when exposed, the association between PBB level and thyroid hormone levels was examined separately

Table 3 Regression coefficients from the association of PBB exposure and thyroid hormone levels in total study population

\begin{tabular}{|c|c|c|c|c|c|c|c|}
\hline & & Total $\mathrm{T}_{4}(\mu \mathrm{g} / \mathrm{dL})$ & Total $T_{3}(\mathrm{ng} / \mathrm{mL})$ & Free $T_{4}(\mathrm{ng} / \mathrm{dL})$ & Free $T_{3}(p g / m L)$ & $\mathrm{TSH}(\mu \mathrm{IU} / \mathrm{mL})$ & $\begin{array}{c}\text { Free } T_{3} \text { : Free } T_{4} \\
\text { ratio }\end{array}$ \\
\hline Model & Variables & $\beta(95 \% \mathrm{Cl})$ & $\beta(95 \% \mathrm{Cl})$ & $\beta(95 \% \mathrm{Cl})$ & $\beta(95 \% \mathrm{Cl})$ & $\beta(95 \% \mathrm{Cl})$ & $\beta(95 \% \mathrm{Cl})$ \\
\hline \multirow[t]{5}{*}{1} & $\begin{array}{l}\text { Total PBB } \\
\text { (ppb) }\end{array}$ & $\begin{array}{c}0.0048 \\
(-0.0041,0.0139)\end{array}$ & $\begin{array}{c}0.0079 \\
(-0.0025,0.0184)\end{array}$ & $\begin{array}{c}-0.0116 \\
(-0.0202,-0.0030)\end{array}$ & $\begin{array}{c}0.0104 \\
(0.0036,0.0172)\end{array}$ & $\begin{array}{c}0.0218 \\
(-0.0110,0.0547)\end{array}$ & $\begin{array}{c}0.0840 \\
(0.0418,0.1262)\end{array}$ \\
\hline & $\begin{array}{l}\text { Current Age } \\
\text { (years) }\end{array}$ & $\begin{array}{c}-0.0006 \\
(-0.0013,0.0012)\end{array}$ & $\begin{array}{c}-0.0056 \\
(-0.0071,-0.0042)\end{array}$ & $\begin{array}{c}0.0005 \\
(-0.0006,0.0017)\end{array}$ & $\begin{array}{c}-0.0028 \\
(-0.0038,-0.0019)\end{array}$ & $\begin{array}{c}0.0032 \\
(-0.0013,0.0078)\end{array}$ & $\begin{array}{c}-0.0141 \\
(-0.0200,-0.0082)\end{array}$ \\
\hline & Sex & $\begin{array}{c}-0.0449 \\
(-0.0763,-0.0136)\end{array}$ & $\begin{array}{c}-0.0154 \\
(-0.0515,0.0212)\end{array}$ & $\begin{array}{c}-0.0004 \\
(-0.0304,0.0294)\end{array}$ & $\begin{array}{c}0.0414 \\
(0.0178,0.0651)\end{array}$ & $\begin{array}{c}0.0311 \\
(-0.0830,0.1452)\end{array}$ & $\begin{array}{c}0.1555 \\
(0.0091,0.3020)\end{array}$ \\
\hline & $\begin{array}{l}\text { Lipids } \\
\text { (mg/dL) }\end{array}$ & $\begin{array}{c}-0.00008 \\
(-0.0001,-0.00001)\end{array}$ & $\begin{array}{c}-0.0001 \\
(-0.0002,-0.0001)\end{array}$ & $\begin{array}{c}-0.00009 \\
(-0.0001,-0.00002)\end{array}$ & $\begin{array}{c}-0.0001 \\
(-0.0001,-0.00009)\end{array}$ & $\begin{array}{c}0.0002 \\
(-0.00001,0.0004)\end{array}$ & $\begin{array}{c}-0.0001 \\
(-0.0004,0.0001)\end{array}$ \\
\hline & $\begin{array}{l}\text { Total PCB } \\
\text { (ppb) }\end{array}$ & $\begin{array}{c}0.0057 \\
(-0.0111,0.0225)\end{array}$ & $\begin{array}{c}0.0181 \\
(-0.0013,0.0377)\end{array}$ & $\begin{array}{c}0.0297 \\
(0.0136,0.0458)\end{array}$ & $\begin{array}{c}-0.0027 \\
(-0.0154,0.0099)\end{array}$ & $\begin{array}{c}-0.0402 \\
(-0.1015,0.0210)\end{array}$ & $\begin{array}{c}-0.1215 \\
(-0.2001,-0.0429)\end{array}$ \\
\hline \multirow[t]{6}{*}{2} & $\begin{array}{l}\text { Total PBB } \\
(\mathrm{ppb})\end{array}$ & $\begin{array}{c}0.0080 \\
(-0.0036,0.0197)\end{array}$ & $\begin{array}{c}0.0173 \\
(0.0038,0.0308)\end{array}$ & $\begin{array}{c}-0.0141 \\
(-0.0252,-0.0029)\end{array}$ & $\begin{array}{c}0.0190 \\
(0.0103,0.0278)\end{array}$ & $\begin{array}{c}0.0240 \\
(-0.0184,0.0665)\end{array}$ & $\begin{array}{c}0.1257 \\
(0.0715,0.1800)\end{array}$ \\
\hline & $\begin{array}{l}\text { Current Age } \\
\text { (years) }\end{array}$ & $\begin{array}{c}-0.00027 \\
(-0.0016,0.0010)\end{array}$ & $\begin{array}{c}-0.0063 \\
(-0.0079,-0.0047)\end{array}$ & $\begin{array}{c}0.0006 \\
(-0.0006,0.0019)\end{array}$ & $\begin{array}{c}-0.0034 \\
(-0.0044,-0.0024)\end{array}$ & $\begin{array}{c}0.0031 \\
(-0.0018,0.0081)\end{array}$ & $\begin{array}{c}-0.0170 \\
(-0.0233,-0.0106)\end{array}$ \\
\hline & Sex & $\begin{array}{c}-0.0434 \\
(-0.0749,-0.0118)\end{array}$ & $\begin{array}{c}-0.0105 \\
(-0.0471,0.0260)\end{array}$ & $\begin{array}{c}-0.0016 \\
(-0.0318,0.0284)\end{array}$ & $\begin{array}{c}0.0457 \\
(0.0220,0.0693)\end{array}$ & $\begin{array}{c}0.0321 \\
(-0.0828,0.1471)\end{array}$ & $\begin{array}{c}0.1759 \\
(0.0290,0.3228)\end{array}$ \\
\hline & $\begin{array}{l}\text { Lipids } \\
\text { (mg/dL) }\end{array}$ & $\begin{array}{c}-0.00008 \\
(-0.0001,-0.00001)\end{array}$ & $\begin{array}{c}-0.0001 \\
(-0.0002,-0.0001)\end{array}$ & $\begin{array}{c}-0.00009 \\
(-0.0001,-0.00002)\end{array}$ & $\begin{array}{c}-0.0001 \\
(-0.0001,-0.00009)\end{array}$ & $\begin{array}{c}0.0002 \\
(-0.00001,0.0004)\end{array}$ & $\begin{array}{c}-0.0001 \\
(-0.0004,0.0001)\end{array}$ \\
\hline & $\begin{array}{l}\text { Total PCB } \\
(\mathrm{ppb})\end{array}$ & $\begin{array}{c}0.0055 \\
(-0.0112,0.0224)\end{array}$ & $\begin{array}{c}0.0177 \\
(-0.0017,0.0372)\end{array}$ & $\begin{array}{c}0.0298 \\
(0.0138,0.0459)\end{array}$ & $\begin{array}{c}-0.0031 \\
(-0.0157,0.0094)\end{array}$ & $\begin{array}{c}-0.0403 \\
(-0.0101,0.0210)\end{array}$ & $\begin{array}{c}-0.1234 \\
(-0.2018,-0.0451)\end{array}$ \\
\hline & $\begin{array}{l}\text { Age } \\
\text { exposed } \times \\
\text { Total PBB }\end{array}$ & $\begin{array}{c}-0.0002 \\
(-0.0009,0.0003)\end{array}$ & $\begin{array}{c}-0.0008 \\
(-0.0016,-0.00007)\end{array}$ & $\begin{array}{c}0.0002 \\
(-0.0004,0.0008)\end{array}$ & $\begin{array}{c}-0.0007 \\
(-0.0012,-0.0002)\end{array}$ & $\begin{array}{c}-0.0001 \\
(-0.0026,0.0022)\end{array}$ & $\begin{array}{c}-0.0038 \\
(-0.0069,-0.0006)\end{array}$ \\
\hline
\end{tabular}




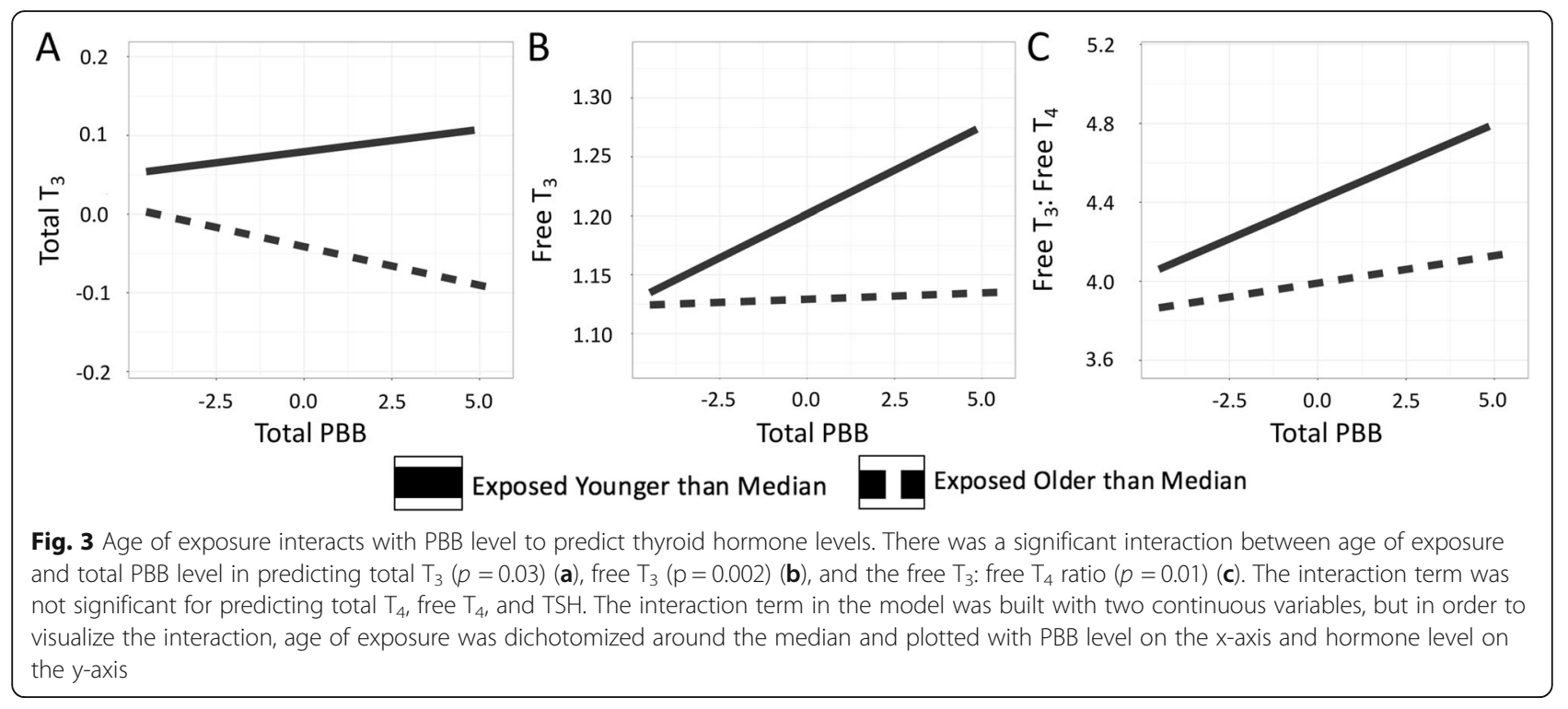

among participants exposed after finishing puberty (age 16) and participants exposed before finishing puberty. In the people that were exposed after finishing puberty, there were no associations between $\mathrm{PBB}$ level and any of the thyroid hormones (total $\mathrm{T}_{4}: \mathrm{t}=-0.40, p=0.68$; total $\mathrm{T}_{3}: \mathrm{t}=-0.56$, $p=0.57$; free $\mathrm{T}_{4}: \mathrm{t}=-0.63, p=0.52$; free $\mathrm{T}_{3}: \mathrm{t}=-0.19, p=$ 0.84; TSH: $\mathrm{t}=0.73, p=0.46$, free $\mathrm{T}_{3}$ : free $\mathrm{T}_{4}$ ratio: $\mathrm{t}=0.44$, $p=0.65$; Fig. 4a). However, among the people who were exposed before finishing puberty, higher PBB was associated with an increase in total $\mathrm{T}_{3}(\mathrm{t}=2.25, p=0.02)$, free $\mathrm{T}_{3}(\mathrm{t}=$ 3.63, $p=0.0003)$, and free $\mathrm{T}_{3}$ : free $\mathrm{T}_{4}$ ratio $(\mathrm{t}=4.00, p=$ 7.40e-5), and a decrease in free $\mathrm{T}_{4}(\mathrm{t}=-2.22, \mathrm{p}=0.02)$.
PBB was not associated with either total $\mathrm{T}_{4}(\mathrm{t}=1.89, p=$ $0.05)$ or TSH $(t=1.32 p=0.18)$ in people exposed before finishing puberty (Fig. $4 \mathrm{~b})$. If instead the sample was stratified by quartile (Additional file 1: Table S8) or median age of exposure (Additional file 1: Table S9), the associations between PBB and thyroid hormone levels were found in the people in the younger groups compared to the oldest group.

\section{Discussion}

This cross-sectional study leveraged data from 715 people who had high exposure to PBB due to a factory
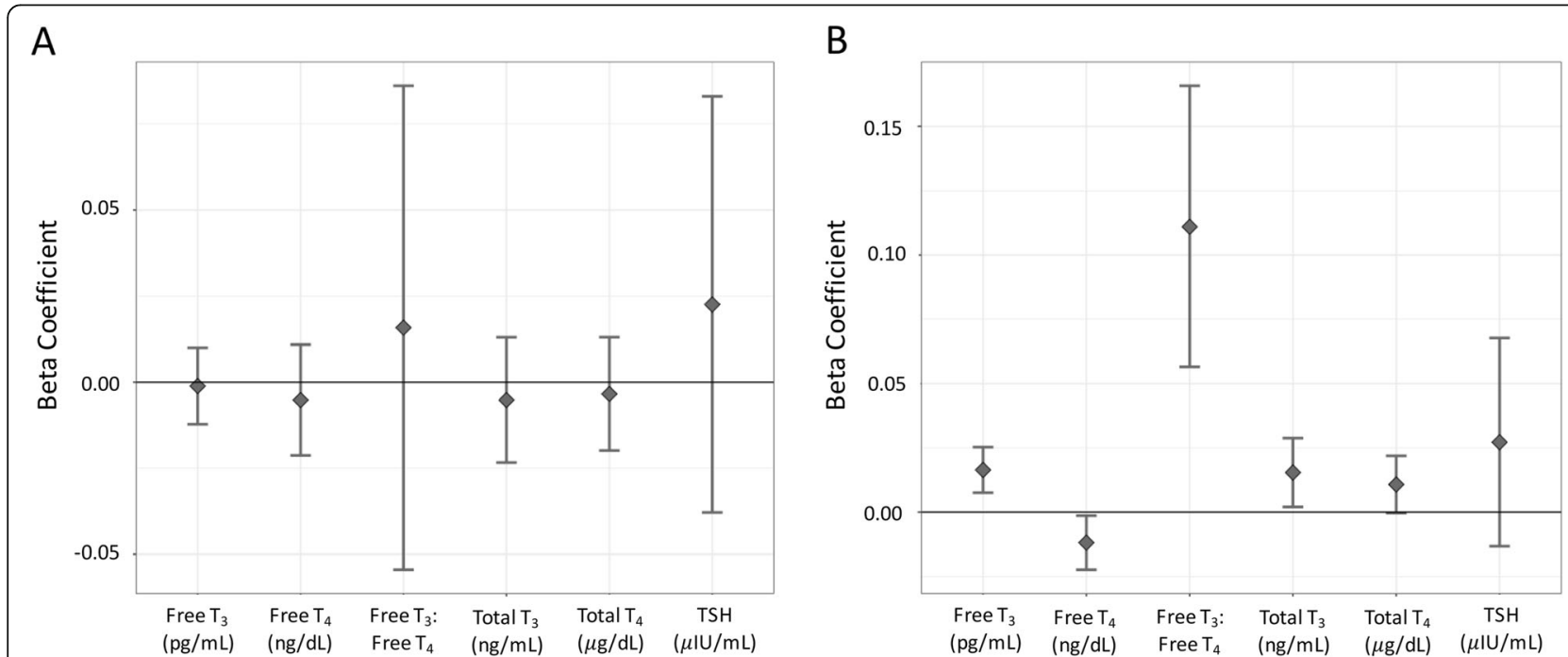

Fig. 4 Association of PBB exposure and thyroid hormone levels stratified by exposure before or after finishing puberty. The total cohort was stratified into people who were either exposed to PBB after finishing puberty (a) or before finishing puberty (b) and the association between total PBB and all six thyroid hormone measures was tested, controlling for age, total PCB level, sex, and lipid levels. PBB and thyroid hormone levels were not associated in the subset exposed after finishing puberty, but in the subset exposed before finishing puberty, PBB and total $T_{3}$ $(p=0.02)$, free $T_{3}(p=0.0003)$, free $T_{4}(p=0.02)$, and the free $T_{3}$ : free $T_{4}$ ratio $(p=7.40 \mathrm{e}-5)$ were associated 
accident over 40 years ago. Among these participants, there was evidence that PBB and PCB disrupted thyroid hormones, with higher $\mathrm{PBB}$ exposure associating with higher free $T_{3}$ and free $T_{3}$ : free $T_{4}$ ratio, and decreased free $\mathrm{T}_{4}$ levels, and PCB being associated with higher free $\mathrm{T}_{4}$ levels and lower free $\mathrm{T}_{3}$ : free $\mathrm{T}_{4}$ ratio. Previous research demonstrated that people exposed to PBBs report higher frequency of thyroid disease (particularly hypothyroidism) [36, 37]. However, in this study, PBBs only associated with lower free $\mathrm{T}_{4}$ and not with higher TSH (when clinical diagnoses of hypothyroidism require a low $\mathrm{T}_{4}$ level and a high TSH level), and with an increase of $\mathrm{T}_{3}$ but not a decrease in TSH (when clinical diagnoses of hyperthyroidism require a high $\mathrm{T}_{3}$ or high $\mathrm{T}_{4}$ level and a low TSH level) [36, 37, 48-50]. This study's findings are consistent with the previous study in a rat model, which reported a decrease in $\mathrm{T}_{4}$. However, that study also found a decrease in $\mathrm{T}_{3}$ [28]. It is possible that this difference in response could be due to differences in dose, with rats being fed a minimum of $5 \mathrm{ppm}$ $\mathrm{PBB}$ (human equivalent of $160 \mathrm{ppm}$ ), where this cohort has a geometric mean exposure of $0.34 \mathrm{ppb}[9,28]$. The negative association between PBB and free $\mathrm{T}_{4}$ is also inconsistent with both the published positive association between PCB and free $T_{4}$ [37] and the positive association between PCB and free $T_{4}$ found in this study. It is not clear why there is a difference in association between free $\mathrm{T}_{4}$ and $\mathrm{PBB}$ or $\mathrm{PCB}$, since the animal study showed a negative association with both $\mathrm{PBB}$ and $\mathrm{PCB}$ and free $\mathrm{T}_{4}$ [28]. However, other studies have found a negative association between $\mathrm{PCB}$ and $\mathrm{T}_{4}$, consistent with the $\mathrm{PBB}$ results [51]. More research is therefore needed to determine whether there are factors, such as dose or the precise mixture of congeners of $\mathrm{PCB}$, that change how PCB and thyroid hormones associate [52].

Even though the associations between thyroid hormone levels and PBB in this study are not entirely consistent with a clinical outcome of thyroid disease, variations in thyroid hormone levels within their normal ranges can still impact health. Variations in thyroid hormone levels within their normal ranges are associated with increased triglycerides, cholesterol levels, BMI, and cardiovascular problems $[53,54]$. For men, higher free $T_{3}$ levels is associated with gynecomastia (enlarged breasts) [55]. For women, subclinical hypothyroidism is associated with adverse pregnancy outcomes, like miscarriage, pre-eclampsia, and subfertility that is unexplained by other sources [56]. Therefore, people with higher exposure to PBBs may be at greater risk for metabolic and reproductive problems even if their thyroid hormone levels are still within the usual population range. This was especially true among the people exposed as children, who also had higher total $T_{3}$, free $T_{3}$, and free $T_{3}$ : free $T_{4}$ ratio and lower free $T_{4}$ with higher exposure to $\mathrm{PBB}$.
This study found stronger associations between PBB and thyroid hormone levels in people who were exposed younger. This is consistent with previous research in this cohort which has found spontaneous miscarriage, offspring with lower Apgar score, and earlier age of menarche in women exposed younger, and genitourinary problems and slower pubertal development in men exposed younger [14-18]. Additionally, it is consistent with studies that have found that developmental stages are particularly vulnerable to disruption from environment contaminants [57, 58]. Finding stronger associations between $\mathrm{PBB}$ exposure and variations in thyroid hormone levels in people exposed younger is of particular concern given that children of women who were exposed can still be exposed to PBBs through placental transfer and breastfeeding. It should be noted that this association was seen in the youngest subset of the study population, regardless of whether the population was divided into quartiles, by median, or by age 16 . Therefore, younger age of exposure is a risk, but other studies would be needed in order to determine the precise window of vulnerability.

Previous work on the association between $\mathrm{PBB}$ and thyroid function in the Michigan PBB Registry has had conflicting results. Some studies found an association between level of PBB exposure and hypothyroidism [36, 37], while others did not demonstrate the same association between PBB and thyroid disease [35]. In the only other study of the association between thyroid hormone levels and PBB exposure level, there was evidence of association between PBB and free $\mathrm{T}_{3}$ levels, but not with other thyroid hormones [37]. However, the current study had almost $30 \%$ more participants ( $N=715$ vs. $N=551)$, and the effect sizes in the total cohort from this study are comparable, but more precise, to what was found previously, indicating that this study had more power to detect a statistical association. Including people in this study who reported a thyroid condition but were not taking medication should not have biased the results, because none of the transformed thyroid hormone levels differed significantly between the current study and the previous study which excluded anyone who had ever been diagnosed with a thyroid problem even if they were not treated with thyroid medication. Additionally, similar to the previous study, we found a negative correlation between free $\mathrm{T}_{4}$ and $\mathrm{PCB}$, and there was a stronger association between $\mathrm{PCB}$ and $\mathrm{PBB}$ and thyroid hormone levels in women. However, given the large overlap of samples in both studies, this should not be viewed as a replication of previous results, but rather as further support for those conclusions and a more detailed exploration of the role of age of exposure in increasing PBB-associated health risks.

This builds upon the previous work in this cohort not only by having a larger sample size and stratifying by age at exposure, but also by analyzing the free $T_{3}$ : free $T_{4}$ ratio. A higher free $T_{3}$ : free $T_{4}$ ratio is associated with 
several metabolic parameters, including insulin resistance, enlarged waist circumference, higher BMI, and blood glucose levels in people without thyroid conditions [23-25]. A higher free $\mathrm{T}_{3}$ : free $\mathrm{T}_{4}$ ratio is also associated with an increased risk for non-alcoholic fatty liver disease in both in euthyroid and hypothyroid individuals, independently of other metabolic parameters [59]. This is of interest given that, in animal models, high exposure to PBBs results in liver pathologies including increased vacuolation and altered drug metabolism in their livers [60-63]. Given the evidence in animal models and the associations reported in human cohorts, it is possible that people that are highly exposed to PBBs may be at increased risk for a variety of metabolic conditions, however, this has not been directly studied in a human cohort.

One possible explanation for finding an association between higher $\mathrm{PBB}$ levels and lower free $\mathrm{T}_{4}$ and higher total $\mathrm{T}_{4}$ (although the association with total $\mathrm{T}_{4}$ was not statistically significant) is that higher PBB exposure is associated with alterations of estrogen levels and an increase in thyroxine-binding globulin (TBG). TBG binds a majority of the $T_{4}$ in blood, rendering it biologically unavailable. One mechanism that leads to increased synthesis of TBG is increased levels of estrogen [64]. While whether higher TBG is associated with lower free $T_{4}$ is still unclear $[48,65]$, previous research has reported that variations in euthyroid, serum levels of total $T_{4}$ are positively associated with urinary estrogen and progesterone levels, and that free $T_{4}$ is associated with shorter cycle and follicular phase length [66]. If the associations between higher PBB and thyroid hormone levels are due to alterations in estrogen levels resulting in higher TBG, it could indicate that PBB is weakly estrogenic. While there is evidence that PBB can alter hormone metabolism in rats $[62,67,68]$, alters menstrual function in monkeys [69], and is associated with earlier pubertal timing in women [15], there is no direct evidence that $\mathrm{PBB}$ is estrogenic at this time, and TBG levels were not measured in this cohort.

Interestingly, this study found that PBB is associated with lower free $T_{4}$ and higher free $T_{3}$ and free $T_{3}$ : free $\mathrm{T}_{4}$ ratio. A majority of thyroid hormone in blood is $\mathrm{T}_{4}$, which is then converted to $\mathrm{T}_{3}$ at the target tissue, and the levels of both negatively regulate TSH. However, finding opposite effects of $\mathrm{PBB}$ on $\mathrm{T}_{3}$ and $\mathrm{T}_{4}$ could be due to $\mathrm{PBB}$ affecting the conversion of $\mathrm{T}_{3}$ to $\mathrm{T}_{4}$ (for example, by PBB altering deiodinase activity) [70]. However, not enough is known about the mechanism behind how $\mathrm{PBB}$ affects thyroid function to fully be able to explain this result. This is not consistent with the findings in animal models, which found extremely high doses of $\mathrm{PBB}$ were associated with decreases in $\mathrm{T}_{3}$ and $\mathrm{T}_{4}$ [28], or with previous studies on PBB and hypothyroidism, which would require both higher $\mathrm{TSH}$ and lower $\mathrm{T}_{4}[36,37]$. Therefore, it is also possible that $\mathrm{PBB}$ affects thyroid function differently at lower doses than at high doses (leading to decreases in $T_{3}$ and $T_{4}$ in animal models and increases in TSH in humans), or that higher $\mathrm{T}_{3}$ and lower $\mathrm{T}_{4}$ is a compensation mechanism for PBB's other effects on cells. Research in model systems could elucidate the cellular mechanisms underlying the effects of PBB on thyroid function.

This study does have limitations. This is an epidemiological study that only measured circulating thyroid hormone levels, and unfortunately, we were not able to measure other factors, such as thyroid ultrasounds, menstrual function, TBG levels, thyroid antibody levels, or oral contraceptive use in the entire study population. Therefore, it is less clear how PBB may mechanistically interfere with thyroid hormone levels. Additionally, there is a lack of information on possible thyroid autoimmunity (which may impact on how EDCs effect the thyroid). Future studies that investigate the effect of $\mathrm{PBB}$ on the thyroid gland itself or whether the immune system is a mediator are warranted, either in different human cohorts or in animal models. Finally, it is not known exactly when these participants were exposed to PCB. Therefore, we were unable to test whether the effects of PCB exposure also depend on when people were exposed.

\section{Conclusions}

This study did find that higher, current $\mathrm{PBB}$ and $\mathrm{PCB}$ levels were associated with thyroid hormone levels. It builds on previous studies that found an increased risk for thyroid disease in women exposed to PBBs and PCBs by leveraging that this cohort was exposed primarily during a narrow time frame to find that there was only an association between higher PBB and thyroid hormone measures in people who were exposed to PBB before puberty. Our finding suggest that this cohort may still be at risk for metabolic- and endocrine-related conditions even 40 years after they were exposed, and that people who are exposed younger may be more vulnerable to the endocrine-disrupting effects of PBBs.

\section{Additional file}

Additional file 1: Figure S1. Correlations of exposure congeners in this cohort. Figure S2. Thyroid hormone levels by subject in this cohort. Table S1. Association of PBB exposure and thyroid hormone levels in subset with thyroid medication status. Table S2. Regression coefficients from the association of PBB exposure and thyroid hormone levels in subset with PBB exposure below the median and PCB exposure below the median ( $N=216$ ). Table S3. Regression coefficients from the association of PBB exposure and thyroid hormone levels in subset with PBB exposure below the median and PCB exposure above the median 
$(N=131)$. Table S4. Regression coefficients from the association of PBB exposure and thyroid hormone levels in subset with PBB exposure above the median and PCB exposure below the median $(N=141)$. Table $\mathbf{S 5}$. Regression coefficients from the association of PBB exposure and thyroid hormone levels in subset with PBB exposure above the median and PCB exposure above the median $(N=227)$. Table S6. Association between PBB and thyroid hormone levels in each gender. Table S7. Association between PCB and thyroid hormone levels in each gender. Table S8. Regression coefficients from the association of PBB exposure and thyroid hormone levels subset by quartile of age of exposure to PBB. Table S9. Regression coefficients from the association of PBB exposure and thyroid hormone levels subset by median of age of exposure to PBB. (DOCX $647 \mathrm{~kb})$

\section{Abbreviations}

EDC: Endocrine-disrupting compound; PBB: Polybrominated biphenyl; PCB: Polychlorinated biphenyl; $\mathrm{T}_{3}$ : Triiodothyronine; $\mathrm{T}_{4}$ : Thyroxine; TBG: Thyroxine-binding globulin; TSH: Thyroid-stimulating hormone

\section{Acknowledgements}

We are grateful to the members of the Michigan PBB Registry for their participation and engagement with research studies over the past 40 years, to the Michigan Department of Health and Human Services which had the foresight to create the Registry, and to our community partners (PBB Citizens Advisory Board, Pine River Superfund Citizen Advisory Group, and the MidMichigan District Health Department) who continue to provide guidance and insight to the Michigan PBB Research.

\section{Authors' contributions}

SWC helped design experiments, performed the data analysis, wrote the manuscript. DOC identified samples for analysis. MLT and MM helped recruit participants and generate the phenotype files for each participant, as well as designed experiments, supervised all analyses, and helped write the manuscript. $\mathrm{MHJ}$ identified samples for analysis and did initial quality control on the thyroid hormone measures. MEM and DBB determined the concentration of PBB in each sample. VSJ, MFN, SAG, and JBS determined if participants were on thyroid medications and should be included in the analysis. KNC and AKS designed experiments, supervised all analyses, and helped write the manuscript. All authors read and approved final manuscript.

\section{Funding}

This work was supported by the National Institute of Environmental Health Sciences (NIEHS; R01ES024790, R01ES025775, R01ES12014, R24ES028528, P30ES019776) and the National Institute of General Medical Sciences (T32GM008490)

\section{Availability of data and materials}

The datasets used and/or analyzed during the current study are available from the corresponding author on reasonable request.

\section{Ethics approval and consent to participate}

Informed consent was obtained from each individual before participation. Study protocols were approved by the Institutional Review Board at Emory University.

\section{Consent for publication}

Not applicable

\section{Competing interests}

The authors declare that they have no competing interests.

\section{Author details}

'Emory University School of Medicine, 101 Woodruff Circle NE, Ste 2205A Atlanta, GA 30322, USA. Emory University Rollins School of Public Health, 1518 Clifton Rd, Atlanta, GA 30322, USA. ${ }^{3}$ Emory University School of Medicine, 615 Michael St, Atlanta, GA 30322, USA.
Received: 17 December 2018 Accepted: 30 July 2019

Published online: 23 August 2019

\section{References}

1. Bergman A, Heindel JJ, Jobling S, Kidd KA, Zoeller RT. State of the science of endocrine disrupting chemicals: World Health Organization; 2012. Available at https://www.who.int/ceh/publications/endocrine/en/. ISBN: 978-92-807-3274-0.

2. Porta M, Pumarega J, Gasull M, Lopez T. Contamination from endocrine disrupters of the general population at low and high concentrations. Vitam Horm. 2014;94:167-92. https://doi.org/10.1016/B978-0-12-800095-3.00006-7 PubMed PMID: 24388190.

3. Xue J, Liu SV, Zartarian VG, Geller AM, Schultz BD. Analysis of NHANES measured blood PCBs in the general US population and application of SHEDS model to identify key exposure factors. J Expo Sci Environ Epidemiol. 2014;24(6):615-21. https://doi.org/10.1038/jes.2013.91 PubMed PMID: 24424407.

4. Gore AC, Chappell VA, Fenton SE, Flaws JA, Nadal A, Prins GS, et al. EDC-2: the Endocrine Society's second scientific statement on endocrine-disrupting chemicals. Endocr Rev. 2015;36(6):E1-E150. https://doi.org/10.1210/er.2015-1 010 PubMed PMID: 26544531: PMCID: PMC4702494.

5. De Coster S, van Larebeke N. Endocrine-disrupting chemicals: associated disorders and mechanisms of action. J Environ Public Health. 2012;2012: 713696. https://doi.org/10.1155/2012/713696 PubMed PMID: 22991565; PMCID: PMC3443608.

6. Meeker JD. Exposure to environmental endocrine disruptors and child development. Arch Pediatr Adolesc Med. 2012;166(6):E1-7. https://doi.org/1 0.1001/archpediatrics.2012.241 PubMed PMID: 22664748; PMCID: PMC3572204.

7. Fries GF. The PBB episode in Michigan: an overall appraisal. Crit Rev Toxicol. 1985;16(2):105-56. https://doi.org/10.3109/10408448509056268 PubMed PMID: 3002722

8. Kay K. Polybrominated biphenyls (PBB) environmental contamination in Michigan, 1973-1976. Environ Res. 1977;13(1):74-93 PubMed PMID: 191251.

9. Curtis SW, Conneely KN, Marder ME, Terrell ML, Marcus M, Smith AK. Intergenerational effects of endocrine-disrupting compounds: a review of the Michigan polybrominated biphenyl registry. Epigenomics. 2018;10(6): 845-58. https://doi.org/10.2217/epi-2017-0174 Epub 2018/06/12. PubMed PMID: 29888951

10. Terrell ML, Manatunga AK, Small CM, Cameron LL, Wirth J, Blanck HM, et al. A decay model for assessing polybrominated biphenyl exposure among women in the Michigan long-term PBB study. J Expo Sci Environ Epidemiol. 2008;18(4):410-20. https://doi.org/10.1038/sj.jes.7500633 PubMed PMID: 18183045; PMCID: PMC5580493.

11. Blanck HM, Marcus M, Hertzberg V, Tolbert PE, Rubin C, Henderson AK, et al. Determinants of polybrominated biphenyl serum decay among women in the Michigan PBB cohort. Environ Health Perspect. 2000:108(2):147-52 PubMed PMID: 10656855; PMCID: PMC1637888.

12. Joseph AD, Terrell ML, Small CM, Cameron LL, Marcus M. Assessing intergenerational transfer of a brominated flame retardant. J Environ Monit. 2009; 11(4):802-7. https://doi.org/10.1039/b816867a PubMed PMID: 19557234.

13. Small CM, Cheslack-Postava K, Terrell M, Blanck HM, Tolbert P, Rubin C, et al. Risk of spontaneous abortion among women exposed to polybrominated biphenyls. Environ Res. 2007;105(2):247-55. https://doi.org/10.1016/j.envres.2 006.11.010 PubMed PMID: 17239850; PMCID: PMC2237897.

14. Small CM, Murray D, Terrell ML, Marcus M. Reproductive outcomes among women exposed to a brominated flame retardant in utero. Arch Environ Occup Health. 2011;66(4):201-8. https://doi.org/10.1080/19338244.2010.53 9640 PubMed PMID: 22014192; PMCID: PMC3964180.

15. Blanck HM, Marcus M, Tolbert PE, Rubin C, Henderson AK, Hertzberg VS, et al. Age at menarche and tanner stage in girls exposed in utero and postnatally to polybrominated biphenyl. Epidemiology. 2000;11(6):641-7 PubMed PMID: 11055623.

16. Terrell ML, Hartnett KP, Lim H, Wirth J, Marcus M. Maternal exposure to brominated flame retardants and infant Apgar scores. Chemosphere. 2015; 118:178-86. https://doi.org/10.1016/j.chemosphere.2014.08.007 PubMed PMID: 25203650; PMCID: PMC4249940.

17. Small CM, DeCaro JJ, Terrell ML, Dominguez C, Cameron LL, Wirth J, et al. Maternal exposure to a brominated flame retardant and genitourinary conditions in male offspring. Environ Health Perspect. 2009;117(7):1175-9. https://doi.org/10.1289/ehp.0800058 PubMed PMID: 19654930; PMCID: PMC2717147. 
18. Small CM, Terrell ML, Cameron LL, Wirth J, Monteilh CP, Marcus M. In utero exposure to a brominated flame retardant and male growth and development. Int J Child Adolesc Health. 2009;2(3).

19. Wu Y, Koenig RJ. Gene regulation by thyroid hormone. Trends Endocrinol Metab. 2000;11(6):207-11 PubMed PMID: 10878749.

20. Liu S, Downes M, Evans RM. Metabolic regulation by nuclear receptors. In: Nakao K, Minato N, Uemoto S, editors. Innovative medicine: basic research and development. Springer: Innovative Medicine; 2015. p. 371-382.

21. Bernal J. Thyroid hormone receptors in brain development and function. Nat Clin Pract Endocrinol Metab. 2007;3(3):249-59. https://doi.org/10.1038/ ncpendmet0424 PubMed PMID: 17315033.

22. Chen PH, Shyu YC, Tsai MY, Lee SY, Yang KC, Yang CJ, Lee TL, Wang $\amalg$. Correlation between attention-deficit/hyperactivity disorder, its pharmacotherapy, and thyroid dysfunction: a nationwide population-based study in Taiwan. Clin Endocrinol 2018. doi: https://doi.org/10.1111/cen.1381 7. PubMed PMID: 30019779.

23. Jang J, Kim Y, Shin J, Lee SA, Choi Y, Park EC. Association between thyroid hormones and the components of metabolic syndrome. BMC Endocr Disord. 2018;18(1):29. https://doi.org/10.1186/s12902-018-0256-0 PubMed PMID: 29783969

24. Urrunaga-Pastor D, Guarnizo-Poma M, Moncada-Mapelli E, Aguirre LG, Lazaro-Alcantara H, Paico-Palacios S, et al. Metabolic syndrome research G. high free triiodothyronine and free-triiodothyronine-to-free-thyroxine ratio levels are associated with metabolic syndrome in a euthyroid population. Diabetes Metab Syndr. 2018;12(2):155-61. https://doi.org/10.1016/j.dsx.201 7.12.003 PubMed PMID: 29254889.

25. Park SY, Park SE, Jung SW, Jin HS, Park IB, Ahn SV, et al. Free triiodothyronine/free thyroxine ratio rather than thyrotropin is more associated with metabolic parameters in healthy euthyroid adult subjects. Clin Endocrinol. 2017;87(1):87-96. https://doi.org/10.1111/cen.13345 PubMed PMID: 28374508.

26. Korevaar T, Minguez-Alarcon L, Messerlian C, de Poortere R, Williams $P$, Broeren $M$, et al. The association of thyroid function and autoimmunity with ovarian reserve in women seeking infertility care. Thyroid. 2018. https://doi. org/10.1089/thy.2017.0582 PubMed PMID: 29943679.

27. Korevaar TIM, Tiemeier H, Peeters RP. Clinical associations of maternal thyroid function with foetal brain development: epidemiological interpretation and overview of available evidence. Clin Endocrinol. 2018. https://doi.org/10.1111/cen.13724 PubMed PMID: 29693263.

28. Byrne JJ, Carbone JP, Hanson EA. Hypothyroidism and abnormalities in the kinetics of thyroid hormone metabolism in rats treated chronically with polychlorinated biphenyl and polybrominated biphenyl. Endocrinology. 1987; 121(2):520-7. https://doi.org/10.1210/endo-121-2-520 PubMed PMID: 3036477.

29. Ibhazehiebo K, Iwasaki T, Okano-Uchida T, Shimokawa N, Ishizaki Y, Koibuchi N. Suppression of thyroid hormone receptor-mediated transcription and disruption of thyroid hormone-induced cerebellar morphogenesis by the polybrominated biphenyl mixture, BP-6. Neurotoxicology. 2011;32(4):400-9. https://doi.org/10.1016/j.neuro.2011.02.008 PubMed PMID: 21396401.

30. Gauger KJ, Giera S, Sharlin DS, Bansal R, lannacone E, Zoeller RT. Polychlorinated biphenyls 105 and 118 form thyroid hormone receptor agonists after cytochrome P4501A1 activation in rat pituitary GH3 cells. Environ Health Perspect. 2007;115(11):1623-30. https://doi.org/10.1289/ehp.1 0328 PubMed PMID: 18007995; PMCID: PMC2072832.

31. You SH, Gauger K, Bansal R, Zoeller RT. 4-Hydroxy-PCB106 acts as a direct thyroid hormone receptor agonist in rat GH3 cells. Mol Cell Endocrinol. 2006;257-258:26-34. https://doi.org/10.1016/j.mce.2006.06.009 PubMed PMID: 16930818 .

32. Gauger KJ, Kato Y, Haraguchi K, Lehmler HJ, Robertson LW, Bansal R, et al. Polychlorinated biphenyls (PCBs) exert thyroid hormone-like effects in the fetal rat brain but do not bind to thyroid hormone receptors. Environ Health Perspect. 2004;112(5):516-23 PubMed PMID: 15064154; PMCID: PMC1241914.

33. Sharlin DS, Bansal R, Zoeller RT. Polychlorinated biphenyls exert selective effects on cellular composition of white matter in a manner inconsistent with thyroid hormone insufficiency. Endocrinology. 2006;147(2):846-58. https://doi.org/10.1210/en.2005-0778 PubMed PMID: 16282356.

34. Bansal R, You SH, Herzig CT, Zoeller RT. Maternal thyroid hormone increases HES expression in the fetal rat brain: an effect mimicked by exposure to a mixture of polychlorinated biphenyls (PCBs). Brain Res Dev Brain Res. 2005;156(1):13-22. https:/doi.org/10.1016/j.devbrainres.2005.01.007 PubMed PMID: 15862623.

35. Yard EE, Terrell ML, Hunt DR, Cameron LL, Small CM, McGeehin MA, et al. Incidence of thyroid disease following exposure to polybrominated biphenyls and polychlorinated biphenyls, Michigan, 1974-2006. Chemosphere. 2011;84(7):863-8. https://doi.org/10.1016/j.chemosphere.2011. 06.020 PubMed PMID: 21737118.

36. Bahn AK, Mills JL, Snyder PJ, Gann PH, Houten L, Bialik O, et al. Hypothyroidism in workers exposed to polybrominated biphenyls. N Engl J Med. 1980;302(1):31-3. https://doi.org/10.1056/NEJM198001033020105 PubMed PMID: 6243165.

37. Jacobson MH, Darrow LA, Barr DB, Howards PP, Lyles RH, Terrell ML, et al. Serum Polybrominated biphenyls (PBBs) and polychlorinated biphenyls (PCBs) and thyroid function among Michigan adults several decades after the 1973-1974 PBB contamination of livestock feed. Environ Health Perspect. 2017;125(9):097020Epub 2017/09/28. PubMed PMID: 28953452; PMCID: PMC Journal - In Process. https://doi.org/10.1289/ehp1302.

38. Safe S. Polychlorinated biphenyls (PCBS) and polybrominated biphenyls (PBBs): biochemistry, toxicology, and mechanism of action. Crit Rev Toxicol. 1984;13(4):319-95. https://doi.org/10.3109/10408448409023762 Epub 1984/ 01/01 PubMed PMID: 6091997.

39. Marder ME, Panuwet $P$, Hunter RE, Ryan PB, Marcus M, Barr DB. Quantification of Polybrominated and polychlorinated biphenyls in human matrices by isotope-dilution gas chromatography-tandem mass spectrometry. J Anal Toxicol. 2016;40(7):511-8. https://doi.org/10.1093/jat/ bkw041 PubMed PMID: 27445313; PMCID: PMC4986627.

40. Helsel DR. Less than obvious - statistical treatment of data below the detection limit. Environ Sci Technol. 1990;24(12):1766-74. https://doi.org/1 0.1021/es00082a001.

41. Phillips DL, Pirkle JL, Burse WW, Bernert JT Jr, Henderson LO, Needham LL. Chlorinated hydrocarbon levels in human serum: effects of fasting and feeding. Arch Environ Contam Toxicol. 1989;18(4):495-500 PubMed PMID: 2505694

42. Bernert JT, Turner WE, Patterson DG Jr, Needham LL. Calculation of serum "total lipid" concentrations for the adjustment of persistent organohalogen toxicant measurements in human samples. Chemosphere. 2007;68(5):824-31. https://doi.org/10.1016/j.chemosphere.2 007.02.043 PubMed PMID: 17408721.

43. Schisterman EF, Whitcomb BW, Louis GM, Louis TA. Lipid adjustment in the analysis of environmental contaminants and human health risks. Environ Health Perspect. 2005;113(7):853-7 PubMed PMID: 16002372; PMCID: PMC1257645.

44. Barr M Jr. Pediatric aspects of the Michigan polybrominated biphenyl contamination. Environ Res. 1980;21(2):255-74 PubMed PMID: 6250815.

45. Walker DI, Marder ME, Yano Y, Terrell M, Liang Y, Barr DB, et al. Multigenerational metabolic profiling in the Michigan PBB registry. Environ Res. 2019;172:182-93. https://doi.org/10.1016/j.envres.2019.02.018 PubMed PMID: 30782538.

46. Lee PA. Normal ages of pubertal events among American males and females. J Adolesc Health Care. 1980;1(1):26-9 PubMed PMID: 6458588.

47. Sjodin A, Wong LY, Jones RS, Park A, Zhang Y, Hodge C, et al. Serum concentrations of polybrominated diphenyl ethers (PBDEs) and polybrominated biphenyl (PBB) in the United States population: 2003-2004. Environ Sci Technol. 2008;42(4):1377-84 PubMed PMID: 18351120.

48. Alexander EK, Pearce EN, Brent GA, Brown RS, Chen H, Dosiou C, et al. 2017 guidelines of the American Thyroid Association for the diagnosis and Management of Thyroid Disease during pregnancy and the postpartum. Thyroid. 2017;27(3):315-89. https://doi.org/10.1089/thy.2016.0457 PubMed PMID: 28056690.

49. Garber JR, Cobin RH, Gharib H, Hennessey JV, Klein I, Mechanick Jl, et al. Clinical practice guidelines for hypothyroidism in adults: cosponsored by the American Association of Clinical Endocrinologists and the American Thyroid Association. Thyroid. 2012;22(12):1200-35. https://doi.org/10.1089/ thy.2012.0205 PubMed PMID: 22954017.

50. Ross DS, Burch HB, Cooper DS, Greenlee MC, Laurberg P, Maia AL, et al. 2016 American Thyroid Association guidelines for diagnosis and Management of Hyperthyroidism and Other Causes of thyrotoxicosis. Thyroid. 2016;26(10):1343421. https://doi.org/10.1089/thy.2016.0229 PubMed PMID: 27521067.

51. Turyk ME, Anderson HA, Persky WW. Relationships of thyroid hormones with polychlorinated biphenyls, dioxins, furans, and DDE in adults. Environ Health Perspect. 2007;115(8):1197-203. https://doi.org/10.1289/ehp.10179 PubMed PMID: 17687447; PMCID: PMC1940071.

52. Kodavanti PR, Kannan N, Yamashita N, Derr-Yellin EC, Ward TR, Burgin DE, et al. Differential effects of two lots of aroclor 1254: congener-specific analysis and neurochemical end points. Environ Health Perspect. 2001;109(11):1153-61. https:// doi.org/10.1289/ehp.011091153 PubMed PMID: 11713001; PMCID: PMC1240477.

53. Jin HY. Prevalence of subclinical hypothyroidism in obese children or adolescents and association between thyroid hormone and the 
components of metabolic syndrome. J Paediatr Child Health. 2018. https:/ doi.org/10.1111/jpc.13926 PubMed PMID: 29768692.

54. Taylor PN, Razvi S, Pearce SH, Dayan CM. Clinical review: a review of the clinical consequences of variation in thyroid function within the reference range. J Clin Endocrinol Metab. 2013;98(9):3562-71. https://doi.org/10.1210/ jc.2013-1315 PubMed PMID: 23824418.

55. Mieritz MG, Sorensen K, Aksglaede L, Mouritsen A, Hagen CP, Hilsted L, et al. Elevated serum levels of free triiodothyronine in adolescent boys with gynaecomastia compared with controls. Eur J Endocrinol. 2014;171(2):193-8. https://doi.org/10.1530/EJE-13-0847 PubMed PMID: 24963134.

56. van den Boogaard E, Vissenberg R, Land JA, van Wely M, van der Post JA, Goddijn M, et al. Significance of (sub)clinical thyroid dysfunction and thyroid autoimmunity before conception and in early pregnancy: a systematic review. Hum Reprod Update. 2011;17(5):605-19. https://doi.org/1 0.1093/humupd/dmr024 PubMed PMID: 21622978

57. Braun JM. Early-life exposure to EDCs: role in childhood obesity and neurodevelopment. Nat Rev Endocrinol. 2017;13(3):161-73. https://doi.org/1 0.1038/nrendo.2016.186 PubMed PMID: 27857130; PMCID: PMC5322271.

58. Heindel JJ, Skalla LA, Joubert BR, Dilworth CH, Gray KA. Review of developmental origins of health and disease publications in environmental epidemiology. Reprod Toxicol. 2017;68:34-48. https://doi.org/10.1016/j. reprotox.2016.11.011 PubMed PMID: 27871864.

59. Gokmen FY, Ahbab S, Ataoglu HE, Turker BC, Cetin F, Turker F, et al. FT3/FT4 ratio predicts non-alcoholic fatty liver disease independent of metabolic parameters in patients with euthyroidism and hypothyroidism. Clinics (Sao Paulo). 2016;71(4):221-5. https://doi.org/10.6061/clinics/2016(04)08 PubMed PMID: 27166773; PMCID: PMC4825197.

60. McCormack KM, Braselton WE Jr, Sanger VL, Hook JB. Residual effects of polybrominated biphenyls following perinatal exposure in rats. Toxicol Appl Pharmacol. 1980;53(1):108-15 PubMed PMID: 6247785.

61. McCormack KM, Melrose P, Rickert DE, Dent JG, Gibson JE, Hook JB. Concomitant dietary exposure to polychlorinated biphenyls and polybrominated biphenyls: tissue distribution and anylhydrocarbon hydroxylase activity in lactating rats. Toxicol Appl Pharmacol. 1979;47(1):95-104 PubMed PMID: 218325.

62. McCormack KM, Lepper LF, Wilson DM, Hook JB. Biochemical and physiological sequelae to perinatal exposure to polybrominated biphenyls: a multigeneration study in rats. Toxicol Appl Pharmacol. 1981;59(2):300-13 PubMed PMID: 6266078.

63. Dent JG, McCormack KM, Rickert DE, Cagen SZ, Melrose P, Gibson JE. Mixed function oxidase activities in lactating rats and their offspring following dietary exposure to polybrominated biphenyls. Toxicol Appl Pharmacol. 1978;46(3):727-35 PubMed PMID: 218324.

64. Ain KB, Refetoff S, Sarne DH, Murata Y. Effect of estrogen on the synthesis and secretion of thyroxine-binding globulin by a human hepatoma cell line, Hep G2. Mol Endocrinol. 1988;2(4):313-23. https://doi.org/10.1210/ mend-2-4-313 PubMed PMID: 2837662.

65. Glinoer D. The regulation of thyroid function in pregnancy: pathways of endocrine adaptation from physiology to pathology. Endocr Rev. 1997;18(3): 404-33. https://doi.org/10.1210/edrv.18.3.0300 PubMed PMID: 9183570.

66. Jacobson MH, Howards PP, Darrow LA, Meadows JW, Kesner JS, Spencer JB, et al. Thyroid hormones and menstrual cycle function in a longitudinal cohort of premenopausal women. Paediatr Perinat Epidemiol. 2018;32(3):225-34. https://doi. org/10.1111/ppe.12462 PubMed PMID: 29517803; PMCID: PMC5980701.

67. Arneric SP, McCormack KM, Braselton WE Jr, Hook JB. Altered metabolism of progesterone by hepatic microsomes from rats following dietary exposure to polybrominated biphenyls. Toxicol Appl Pharmacol. 1980;54(2):187-96 PubMed PMID: 6252660.

68. Newton JF, Braselton WE Jr, Lepper LF, McCormack KM, Hook JB. Effects of polybrominated biphenyls on metabolism of testosterone by rat hepatic microsomes. Toxicol Appl Pharmacol. 1982;63(1):142-9 PubMed PMID: 6280342.

69. Lambrecht LK, Barsotti DA, Allen JR. Responses of nonhuman primates to a polybrominated biphenyl mixture. Environ Health Perspect. 1978;23:139-45 PubMed PMID: 209967; PMCID: PMC1637449.

70. Marsili A, Zavacki AM, Harney JW, Larsen PR. Physiological role and regulation of iodothyronine deiodinases: a 2011 update. J Endocrinol Investig. 2011;34(5):395-407. https://doi.org/10.3275/7615 1007/BF03347465. PubMed PMID: 21427525; PMCID: PMC3687787.

\section{Publisher's Note}

Springer Nature remains neutral with regard to jurisdictional claims in published maps and institutional affiliations.

Ready to submit your research? Choose BMC and benefit from:

- fast, convenient online submission

- thorough peer review by experienced researchers in your field

- rapid publication on acceptance

- support for research data, including large and complex data types

- gold Open Access which fosters wider collaboration and increased citations

- maximum visibility for your research: over $100 \mathrm{M}$ website views per year

At BMC, research is always in progress.

Learn more biomedcentral.com/submissions 